Radio Adulp: La universidad que queremos es parte inseparable del país que anhelamos

Manuel Rodríguez - Gustavo Castro García

Question/Cuestión, Vol. 2, № 66, Agosto 2020

ISSN 1669-6581

https://perio.unlp.edu.ar/ojs/index.php/question/index

IICom-FPyCS-UNLP

\section{RADIO ADULP: LA UNIVERSIDAD QUE QUEREMOS ES PARTE INSEPARABLE DEL PAÍS QUE ANHELAMOS}

\section{ADULP RADIO: THE COLLEGE WE WANT IS AN INSEPARABLE PART OF THE COUNTRY WE LONG FOR}

\begin{abstract}
Manuel Rodríguez
Licenciado en Comunicación Social (UNLP). Docente FPyCS/UNLP. Secretario de Comunicación y Prensa de la Asociación de Docentes de la Universidad de La Plata (ADULP). mrodriguez@perio.unlp.edu.ar
\end{abstract}

\section{Entrevista Sonora de Gustavo Castro García}

Periodista y Licenciado en Comunicación Social Docente ayudante de primera del Taller de Producción de Contenidos y

Narrativas Sonoras y Radiales. FPyCS - UNLP 
Integrante del Equipo de Prensa y Comunicación de la Asociación de Docentes de la Universidad de La Plata castrogarcia@gmail.com

\section{Resumen}

En el marco del aniversario de los 100 años de la radio argentina, desde el Taller de Producción de Contenidos y Narrativas Sonora y Radiales entrevistamos a Manuel Rodríguez, Docente de FPyCS y Secretario de Comunicación y Prensa de la Asociación de Docentes de la Universidad de La Plata (ADULP). Nos cuenta la experiencia de Radio Adulp y la relación de este medio con las políticas de la Asociación de Docentes de la Universidad de La Plata.

\section{Palabras clave}

Radio, ADULP, Docentes, Universidad, Sindicato

\section{Abstract}

In the framework of the 100-year anniversary of Argentine radio, from the Sonora and Radio Content and Narrative Production Workshop, we interviewed Manuel Rodríguez, Professor of the Faculty of Journalism and Social Communication and Secretary of Communication and Press of the Association of Teachers of the University of La Plata (ADULP).

He tells us about the experience of Radio Adulp and the relationship of this medium with the policies of the Association of Teachers of the University of La Plata. 


\section{Keywords}

Radio, ADULP, Teachers, University, Union

\section{Enlace}

https://go.ivoox.com/rf/55621892 